\title{
Review of Medicinal uses, Phytochemistry and Biological Activities of Antidesma laciniatum and A. membranaceum
}

\author{
Alfred Maroyi
}

\author{
Department of Botany, University of Fort Hare, Private Bag X1314, Alice 5700, South Africa
}

\begin{abstract}
Antidesma laciniatum and A. membranaceum are small trees used as traditional medicines in tropical Africa. This extensive literature review synthesizes the information currently available on the medicinal uses, phytochemistry and biological activities of $A$. laciniatum and $A$. membranaceum. The university library and electronic search engines such as Google Scholar, Scopus, Web of Science, ScienceDirect, and PubMed were searched for pertinent information on the medicinal uses, phytochemistry, and biological activities of $A$. laciniatum and $A$. membranaceum. Traditionally, the species have been used as aphrodisiac, and traditional medicine for cough, kwashiorkor, mouth ulcers, pneumonia, prevent miscarriage, snakebites, stomachache and wounds. Various phytochemicals such as essential oils, isoflavonoid glycosides, phytosterols, benzopyranones, lignin glucosides, megastigmane, phenolics, steroids, squalene, terpenoids, triterpenoids, and tetrahydroisoquinoline alkaloids have been isolated from $A$. laciniatum and $A$. membranaceum. In vitro studies have confirmed the biological activities of $A$. laciniatum and $A$. membranaceum which, include antimicrobial, antioxidant, antiplasmodial, antitrypanosomal, leishmanicidal, molluscicidal and cytotoxicity activities. More pharmacological studies including phytochemical, toxicological, in vitro and in vivo experiments are needed to provide evidence for the clinical effectiveness of remedies prepared from the species.
\end{abstract}

Keywords: Antidesma laciniatum, Antidesma membranaceum, indigenous knowledge, Phyllanthaceae, traditional medicine, tropical Africa.

\section{INTRODUCTION}

The genus Antidesma L. is one of the most important sources of herbal medicines among the Phyllanthaceae family. Moreover, the Phyllanthaceae species have been used in folk medicine in several countries in the treatment of skin infections, kidney and urinary bladder problems, sexually transmitted infections, gastro-intestinal infections, respiratory infections, wounds, hypertension, and diabetes [1-4]. The Phyllanthaceae species are reported to have pharmacological activities such as anti-inflammatory, antitumour, analgesic, antimicrobial, antineoplastic, antiplasmodial, antihepatoxic, antioxidant, mutagenic, hepatoprotective, hypotensive and antiallergic [1-9]. Similarly, species belonging to the genus Antidesma are widely used in tropical Africa as food sources and traditional medicines [10-12]. Some Antidesma species, for example A. madagascariense Lam. are characterized by sterols, phenols, saponins, tannins, alkaloids, flavonoids, cyanogenetic heterosides, leucoanthocyanins, triterpenes and carpusin [12]. The crude extracts of $A$. madagascariense showed antibacterial, antifungal, antioxidant, antiglycation, antidiabetic activities as well as its immunomodulatory properties [12]. Antidesma laciniatum Müll. Arg. and A. membranaceum Müll. Arg. are among the species

*Address correspondence to this author at the Department of Botany, University of Fort Hare, Private Bag X1314, Alice 5700, South Africa;

Tel/Fax: 0027719600326; E-mail: amaroyi@ufh.ac.za widely used as herbal medicines in tropical Africa [13]. Antidesma laciniatum and $A$. membranaceum have been recorded in overlapping geographical areas in tropical Africa, extending from Guinea Bissau eastwards to Ethiopia and Kenya, through the Democratic Republic of Congo (DRC) southwards to central and southern Africa [13]. It is, therefore, within this context that the current review was undertaken aimed at providing a comparative analysis of the botanical, medicinal, chemical and biological activities of $A$. laciniatum and $A$. membranaceum.

\section{Botanical Description}

Antidesma laciniatum is a shrub or small dioecious tree with a spreading crown growing to a height of 15 metres [14]. The leaves of $A$. laciniatum are alternate, simple, entire, and linear to oblong in shape. Antidesma laciniatum has been recorded in the understorey of dense forests, rain forests, moist deciduous forests, including secondary forest and forest edges from sea level to 1200 metres above sea level [14-16]. Antidesma membranaceum is a shrub or a small dioecious tree of about 20 metres in height with a dense crown $[17,18]$. The bole of $A$. membranaceum is fluted and there are small buttresses on larger trees. The bark of $A$. membranaceum is rough and dark brown in colour in older specimens while young branchlets are characterized by brown, velvety hairs. The leaves are alternate, simple, entire, narrowly elliptic to oblong in shape, dark green and velvety

(C) 2020 SET Publisher 
above and yellowish below. Antidesma membranaceum has been recorded in mixed and moist woodland, evergreen forest, riverine vegetation, ravines, fringe forest, lakeshores, coastal forest, thicket and woodlands in the savanna biome from sea level to 1850 metres above sea level [19-29].

The bark, fruit, leaf, root, seed and stem decoction or infusion of $A$. laciniatum and $A$. membranaceum are mainly used as aphrodisiac, and as traditional medicine for cough, kwashiorkor, mouth ulcers, pneumonia, prevent miscarriage, snakebites, stomachache and wounds (Table 1). Other medicinal applications of $A$. membranaceum that are supported by at least two literature reports include the use of the bark, leaf, root and seed infusion or decoction, as an anthelmintic
$[13,30]$, aphrodisiac $[10,13]$, chest problems $[10,13]$ and colic $[10,13]$.

\section{Phytochemistry}

A variety of chemical compounds have been isolated and identified from the leaves and stem bark of A. laciniatum, including essential oils, isoflavonoid glycosides, phytosterols, squalene, terpenoids, and triterpenoids [33,47-50] (Table 2). Similarly, compounds such as benzopyranones, lignin glucosides, megastigmane, phenolics, steroids, terpenoids and tetrahydroisoquinoline alkaloids have been isolated and identified from the bark, leaves, roots, root bark and stem bark of $A$. membranaceum [48,51-56]. Some of these phytochemical compounds

Table 1: Medicinal uses of Antidesma laciniatum and A. membranaceum

\begin{tabular}{|c|c|c|c|}
\hline Medicinal uses & Part used & Country & Reference \\
\hline \multicolumn{4}{|l|}{ A. laciniatum } \\
\hline Aphrodisiac & Bark decoction taken orally & Cameroon and Guinea & [31-33] \\
\hline Bleeding & Fruit decoction applied topically & Angola & {$[34]$} \\
\hline Cough & Stem decoction taken orally & Cameroon & {$[35]$} \\
\hline Fish poison & Leaves and roots & Central African Republic & {$[36]$} \\
\hline Prevent miscarriage & Leaf decoction taken orally & Guinea & [32] \\
\hline \multicolumn{4}{|l|}{ A. membranaceum } \\
\hline Anthelmintic & Seed decoction taken orally & Tanzania & {$[13,30]$} \\
\hline Aphrodisiac & Bark decoction taken orally & Côte d'Ivoire & {$[10,13]$} \\
\hline Asthma & Bark and leaf decoction taken orally & DRC & [37] \\
\hline Chest problems & Leaf and root infusion taken orally & Zimbabwe & {$[10,13]$} \\
\hline Colic & Root infusion taken orally & DRC & {$[10,13]$} \\
\hline Cosmetic & Milky juice applied topically & Liberia & [38] \\
\hline Cough & Leaf and root infusion taken orally & DRC and Zimbabwe & {$[10,13,39,40]$} \\
\hline Diabetes & Bark and leaf decoction taken orally & DRC & [37] \\
\hline Diarrhoea & Bark and leaf decoction taken orally & DRC & [37] \\
\hline Flu & Stem decoction taken orally & Tanzania & [41] \\
\hline Hernia & Bark and leaf decoction taken orally & DRC & {$[37]$} \\
\hline Kwashiorkor & Root decoction taken orally & Tanzania & {$[11,13,30,42,43]$} \\
\hline Mouth ulcers & Root decoction taken orally & DRC and Tanzania & {$[11,13,30,40,43]$} \\
\hline Pneumonia & Root decoction taken orally & Tanzania & {$[11,13,30,43]$} \\
\hline Prevent miscarriage & Leaf decoction used as a bath & Liberia & {$[10,13,32,44-46]$} \\
\hline Snakebites & Leaf and root infusion applied topically & DRC and Tanzania & {$[10,11,13]$} \\
\hline Stomachache & Leaf and root infusion taken orally & DRC & {$[10,11,13,45,46]$} \\
\hline Tonic & Root infusion taken orally & Tanzania & [11] \\
\hline Wounds & Stem bark powder applied topically & DRC and Tanzania & {$[13,30,40]$} \\
\hline
\end{tabular}


Table 2: Phytochemical Compounds of Antidesma laciniatum and A. membranaceum

\begin{tabular}{|c|c|c|c|}
\hline Compound & Value & Plant part & Reference \\
\hline \multicolumn{4}{|l|}{ A. laciniatum } \\
\hline 30-hydroxybetulinic acid & - & Stem bark & [49] \\
\hline 30-oxobetulinic acid & - & Stem bark & [49] \\
\hline Benzyl benzoate (\%) & 19.1 & Leaves & {$[33,47]$} \\
\hline Benzyl salicylate (\%) & 3.0 & Leaves & {$[33,47]$} \\
\hline Betulinic acid & - & Stem bark & {$[49,50]$} \\
\hline$\beta$-Bourbonene (\%) & 0.5 & Leaves & {$[33,47]$} \\
\hline a-Cadinol (\%) & 3.0 & Leaves & {$[33,47]$} \\
\hline epi-a-Cadinol (\%) & 0.2 & Leaves & {$[33,47]$} \\
\hline$\beta$-Caryophyllene (\%) & 5.2 & Leaves & {$[33,47]$} \\
\hline Caryophyllene oxide (\%) & 8.5 & Leaves & {$[33,47]$} \\
\hline Chevalierinosides A - C & - & Stem bark & {$[49,50]$} \\
\hline (E)-Cinnamyl acetate (\%) & 0.6 & Leaves & {$[33,47]$} \\
\hline a-Copaene (\%) & 2.2 & Leaves & {$[33,47]$} \\
\hline$\beta$-Copaene (\%) & 0.3 & Leaves & {$[33,47]$} \\
\hline Geraniol (\%) & 0.5 & Leaves & {$[33,47]$} \\
\hline Geranyl acetate (\%) & 14.9 & Leaves & {$[33,47]$} \\
\hline Germacrene D (\%) & 8.5 & Leaves & {$[33,47]$} \\
\hline Germacrene D-4-ol (\%) & 0.4 & Leaves & {$[33,47]$} \\
\hline a-Humulene (\%) & 2.1 & Leaves & {$[33,47]$} \\
\hline Humulene oxide (\%) & 3.5 & Leaves & {$[33,47]$} \\
\hline Kaempferol 3-O- $\beta$-D-glucopyranoside & - & Stem bark & [49] \\
\hline Linalool (\%) & 9.4 & Leaves & {$[33,47]$} \\
\hline Methyl benzoate (\%) & 0.5 & Leaves & {$[33,47]$} \\
\hline p-Methyl anisole (\%) & 2.1 & Leaves & {$[33,47]$} \\
\hline a-Muurolene (\%) & 1.5 & Leaves & {$[33,47]$} \\
\hline Y-Muurolene (\%) & 0.7 & Leaves & {$[33,47]$} \\
\hline a-Muurolol (\%) & 1.0 & Leaves & {$[33,47]$} \\
\hline epi-a-Muurolol (\%) & 2.5 & Leaves & {$[33,47]$} \\
\hline Squalene & - & Leaves & [48] \\
\hline Sitosterol & - & Leaves & [48] \\
\hline Spathulenol (\%) & 1.4 & Leaves & {$[33,47]$} \\
\hline
\end{tabular}


(Table 2). Continued.

\begin{tabular}{|c|c|c|c|}
\hline Compound & Value & Plant part & Reference \\
\hline \multicolumn{4}{|l|}{ A. membranaceum } \\
\hline 2-Nonadecyl-2,5,7-trihydroxy-chromanone & - & Leaves, roots and stem bark & {$[51]$} \\
\hline 2-Eicosyl-2,5,7-trihydroxy-chromanone & - & Leaves, roots and stem bark & {$[51]$} \\
\hline 2-Heneicosyl-2,5,7-trihydroxy-chromanone & - & Leaves, roots and stem bark & {$[51]$} \\
\hline 3-oxo- $\alpha$-ionyl $\beta$-D-glucopyranoside & - & Leaves & {$[55]$} \\
\hline 4'-O-methyllyoniresin-4-yl $\beta$-D-glucopyranoside & - & Leaves & {$[55]$} \\
\hline $\begin{array}{c}\text { (5S)-I,4-Dimethoxy-3-methyl-5-octyl-5,6,7,8-tetrahydroisoquinolin-8- } \\
\text { one }\end{array}$ & - & Bark, leaves and roots & {$[52]$} \\
\hline 5,7-Dihydroxy-2-heneicosyl-chromone & - & Leaves, roots and stem bark & {$[51]$} \\
\hline 5,7-Dihydroxy-2-nonadecyl-chromone & - & Leaves, roots and stem bark & {$[51]$} \\
\hline 5,7-Dihydroxy-2-eicosyl-chromone & - & Leaves, roots and stem bark & {$[51]$} \\
\hline 8,8-bis(dihydroconiferyl)-diferuloylate & - & Leaves, roots and stem bark & {$[51]$} \\
\hline (17RS)-17-( $\beta$-D-glucopyranosyloxy)antidesmone & - & Leaves & {$[55]$} \\
\hline (17RS)-8-deoxo-17-( $\beta$-D-glucopyranosyloxy)antidesmone & - & Leaves & {$[55]$} \\
\hline Amentoflavone & - & Leaves & {$[48]$} \\
\hline Antidesmone & - & Bark, leaves and roots & {$[52-55]$} \\
\hline Blumenyl A $\beta$-D-glucopyranoside & - & Leaves & {$[55]$} \\
\hline Blumenyl B $\beta$-D-glucopyranoside & - & Leaves & {$[55]$} \\
\hline Blumenyl C $\beta$-D-glucopyranoside & - & Leaves & {$[55]$} \\
\hline Lyoniresin-4-yl $\beta$-D-glucopyranoside & - & Leaves & {$[55]$} \\
\hline N-trans-feruloyl-octopamine & - & Leaves, roots and stem bark & {$[51]$} \\
\hline $\mathrm{N}$-cis-feruloyl-octopamine & - & Leaves, roots and stem bark & {$[51]$} \\
\hline N-trans-feruloyl tyramine & - & Leaves, roots and stem bark & {$[51]$} \\
\hline Secoisolariciresin-4-yl $\beta$-D-glucopyranoside & - & Leaves & {$[55]$} \\
\hline (-)-Syringaresinol & - & Leaves, roots and stem bark & {$[51]$} \\
\hline
\end{tabular}

may be responsible for the pharmacological properties exhibited by the two species.

\section{Biological Activities}

Pharmacological research revealed that different extracts of $A$. laciniatum and $A$. membranaceum, and the compounds isolated from the species have various biological activities such as antimicrobial, antioxidant, antiplasmodial, antitrypanosomal, leishmanicidal, molluscicidal, and cytotoxicity activities.

\section{Antimicrobial Activities}

Preliminary antibacterial activity evaluations of aqueous and methanol leaf extracts of $A$. membranaceum carried out by Ogunlana and Ramstad [57] revealed activities against Bacillus subtilis. Magadula et al. [56] evaluated the antimycobacterial activities of ethanol extracts of $A$. membranaceum root bark against Mycobacterium madagascariense and Mycobacterium indicus pranii using the two-fold microdilution method with ciprofloxacin as a positive control. The extract exhibited activities against Mycobacterium indicus pranii and Mycobacterium madagascariense with the minimum inhibition concentration (MIC) values of $0.3 \mathrm{mg} / \mathrm{ml}$ and 1.3 $\mathrm{mg} / \mathrm{ml}$, respectively, in comparison to a MIC value of $<0.05 \mathrm{mg} / \mathrm{ml}$ exhibited by the positive control [56]. The compound antidesmone isolated from the bark, leaves and roots of $A$. membranaceum exhibited antifungal activities to the amount of $1.25 \mathrm{nmol}$ in a bioassay based on Cladosporium cucumerinum [52].

\section{Antioxidant Activities}

Boyom et al. [47] evaluated the antioxidant activities of the essential oils isolated from the leaves of $A$. laciniatum using 2,2-diphenyl-1-picrylhydrazyl (DPPH) 
free radical scavenging assay with ascorbic acid (10.0 - $50.0 \mu \mathrm{M})$, butylated hydroxytoluene (BHT) (10.0 $50.0 \mu \mathrm{M})$ and $\delta$-tocopherol $(10.0-50.0 \mu \mathrm{M})$ as positive controls. The essential oils exhibited weak activities with half maximal scavenging concentrations $\left(\mathrm{SC}_{50}\right)$ value of $25.0 \mathrm{~g} / \mathrm{l}$ in comparison to the $\mathrm{SC}_{50}$ values of $6.2 \mathrm{mg} / \mathrm{l}$ to $15.3 \mathrm{mg} / \mathrm{l}$ exhibited by the positive controls [47].

\section{Antiplasmodial Activities}

Bringmann et al. [54] evaluated the antiplasmodial activities of the compound antidesmone isolated from the stem bark of $A$. membranaceum against NF54 strain of Plasmodium falciparum, which is sensitive to all known drugs and $\mathrm{K} 1$, a strain resistant to chloroquine and pyrimethamine using the $\left[\mathrm{G}^{3}{ }^{3} \mathrm{H}\right]-$ hypoxanthine incorporation assay with chloroquine as a positive control. The compound exhibited weak activities against $\mathrm{K} 1$ and NF54 with the median inhibitory concentration $\left(\mathrm{IC}_{50}\right)$ values of $3.8 \mu \mathrm{g} / \mathrm{ml}$ and $>5.0 \mu \mathrm{g} / \mathrm{ml}$, respectively [54]. Boyom et al. [47] evaluated the antiplasmodial activities of the essential oils isolated from the leaves of $A$. laciniatum against the W2 strain of Plasmodium falciparum using the [G- ${ }^{3}$ $\mathrm{H}]$-hypoxanthine incorporation assay with chloroquine phosphate as a positive control. The essential oils exhibited activities with an $\mathrm{IC}_{50}$ value of $29.4 \mu \mathrm{g} / \mathrm{ml}$ in comparison to an $\mathrm{IC}_{50}$ value of $30.4 \mathrm{nM}$ exhibited by the positive control [47].

\section{Antitrypanosomal Activities}

Bringmann et al. [54] evaluated the antitrypanosomal activities of the compound antidesmone isolated from the stem bark of $A$. membranaceum against Trypanosoma brucei rhodesiense and Trypanosoma cruzi using the Alamar Blue assay, and rat skeletal myoblasts (L-6 cells) infected with trypomastigotes of Trypanosoma cruzi. The compound exhibited activities against Trypanosoma cruzi, rat skeletal myoblasts (L-6 cells) and Trypanosoma brucei rhodesiense with $\mathrm{IC}_{50}$ values of $0.02 \mu \mathrm{g} / \mathrm{ml}, 11.8 \mu \mathrm{g} / \mathrm{ml}$ and $20.1 \mu \mathrm{g} / \mathrm{ml}$, respectively [54].

\section{Leishmanicidal Activities}

Bringmann et al. [54] evaluated the leishmanicidal activities of the compound antidesmone isolated from the stem bark of $A$. membranaceum against Leishmania donovani using mouse peritoneal macrophages. The compound exhibited weak activities with an $\mathrm{IC}_{50}$ value of $7.2 \mu \mathrm{g} / \mathrm{ml}$ [54].

\section{Molluscicidal Activities}

Adewunmi and Sofowora [58] evaluated the molluscicidal activities of methanol extracts of $A$. laciniatum roots against Bulinus globosus. The extract showed $100 \%$ mortality to the snails at a concentration of $100.0 \mathrm{ppm}$ [58].

\section{Cytotoxicity Activities}

Magadula et al. [56] evaluated the cytotoxicity activities of ethanol extracts of $A$. membranaceum root bark using the brine shrimp toxicity assay with cyclophosphamide as a positive control. The extract exhibited activities with half maximal lethal concentration $\left(\mathrm{LC}_{50}\right.$ ) value of $36.1 \mu \mathrm{g} / \mathrm{ml}$ in comparison to $L_{50}$ value of $16.3 \mu \mathrm{g} / \mathrm{ml}$ exhibited by the positive control [56].

\section{CONCLUSION}

The present review summarizes the medicinal uses, phytochemistry and biological activities of $A$. laciniatum and $A$. membranaceum. Based on the presented information, these two species are closely related and deemed as potent traditional medicines for treating and managing cough, kwashiorkor, mouth ulcers, pneumonia, prevent miscarriage, snakebites, stomach ache, and wounds. Antidesma laciniatum and A. membranaceum should be subjected to detailed phytochemical, pharmacological, and toxicological evaluations aimed at correlating their medicinal uses with their phytochemistry and pharmacological properties.

\section{CONFLICT OF INTEREST}

No conflict of interest is associated with this work.

\section{REFERENCES}

[1] Kumaran A, Karunakaran RJ. In vitro antioxidant activities of methanol extracts of five Phyllanthus species from India. LWT Food Sci Technol 2007; 40: 344-52. https://doi.org/10.1016/j.Iwt.2005.09.011

[2] Ramasamy S, et al. Cytotoxicity evaluation of five selected Malaysian Phyllanthaceae species on various human cancer cell lines. J Med Plants Res 2011; 5(11): 2267-73.

[3] Sarin B, et al. An overview of important ethnomedicinal herbs of Phyllanthus species: Present status and future prospects. Sci World J 2014, article ID 839172. https://doi.org/10.1155/2014/839172

[4] Geethangili M, Ding S-T. A review of the phytochemistry and pharmacology of Phyllanthus urinaria L. Front Pharmacol 2018; 9: 1109.

https://doi.org/10.3389/fphar.2018.01109

[5] Calixto JB, et al. A review of the plants of the genus Phyllanthus: Their chemistry, pharmacology and therapeutic potential. Med Res Rev 1998; 18(4): 225-58.

https://doi.org/10.1002/(SICI)1098-

1128(199807)18:4<225::AID-MED2>3.0.CO;2-X 
[6] Harish R, Shivanandappa T. Antioxidant activity and hepatoproctective potential of Phyllanthus niruri. Food Chem 2006; 93: 180-5. https://doi.org/10.1016/j.foodchem.2004.11.049

[7] Jagessar RC, Mars A, Gomes G. Selective antimicrobial properties of Phyllanthus acidus leaf extract against Candida albicans, Escherichia coli and Staphylococcus aureus using stokes disc diffusion, well diffusion, streak plate and a dilution method. Nat Sci 2008; 6(2): 24-38.

[8] Sabir SM, Rocha JBT. Water-extractable phytochemicals from Phyllanthus niruri exhibit distinct in vitro antioxidant and in vivo hepatoprotective activity against paracetamol-induced liver damage in mice. Food Chem 2008; 111(4): 845-51. https://doi.org/10.1016/j.foodchem.2008.04.060

[9] Leeya $\mathrm{Y}$, et al. Hypotensive activity of an n-butanol extract and their purified compounds from leaves of Phyllanthus acidus (L.) Skeels in rats. Eur J Pharmacol 2010; 649: 30113.

\section{https://doi.org/10.1016/j.ejphar.2010.09.038}

[10] Burkill HM. The useful plant of west tropical African. Richmond: Royal Botanic Gardens, Kew; 1985.

[11] Lovett JC, et al. Field guide to the moist forest trees of Tanzania. York: University of York; 2007.

[12] Mahomoodally MF, Korumtollee HN, Chady ZZBK. Ethnopharmacological uses of Antidesma madagascariense Lam. (Euphorbiaceae). J Intercult Ethnopharmacol 2015; 4(1): 86-9. https://doi.org/10.5455/jice.20141202055655

[13] Schmelzer GH. Antidesma membranaceum Müll. Arg. In Schmelzer GH, Gurib-Fakim A (Eds.), Plant resources of tropical Africa 11: Medicinal plants 1. Leiden: Backhuys Publishers; 2008, pp. 103-4.

[14] Carter S, Radcliffe-Smith A. Euphorbiaceae part 2. In Polhill RM (Ed.), Flora of tropical east Africa. Rotterdam: AA Balkema; 1988, pp. 409-597.

[15] Fonge BA, Tchetcha DJ, Nkembi L. Diversity, distribution, and abundance of plants in Lewoh-Lebang in the Lebialem highlands of southwestern Cameroon. Int J Biod 2013, article ID 642579.

https://doi.org/10.1155/2013/642579

[16] Sonké B, Couvreur T. Tree diversity of the Dja Faunal Reserve, southeastern Cameroon. Biod Data J 2014; 2: e1049.

https://doi.org/10.3897/BDJ.2.e1049

[17] Radcliffe-Smith A. Euphorbiaceae, subfamilies Phyllantoideae, Oldfieldioideae, Acalyphoideae, Crotonoideae and Euphorbioideae, tribe Hippomaneae. In Pope GV (Ed.), Flora Zambesiaca volume 9 part 4. Richmond: Royal Botanic Gardens, Kew; 1996, pp. 1-337.

[18] Palgrave MC. Keith Coates Palgrave trees of southern Africa. Cape Town: Struik Publishers; 2002.

[19] Greenway PJ, et al. The vegetation of Mafia Island, Tanzania. Kirkia 1988; 13(1): 197-238.

[20] Louppe D, Oattara N, Coulibaly A. The effects of brush fires on vegetation: the Aubréville fire plots after 60 years. Commonwealth For Rev 1995; 74(4): 288-92.

[21] Sunderland $\mathrm{TCH}$, et al. Vegetation assessment of Takamanda Forest Reserve, Cameroon. In Comiskey JA, Sunderland $\mathrm{TCH}$, Sunderland-Groves JL (Editors), Takamanda: The biodiversity of an African rainforest. Washington DC: Smithsonian Institution, SI/MAB series no. 8; 2003.

[22] Akoègninou $A$, Van der Burg WJ, Van der Maesen LJG. Flore analytique du Bénin. Leiden: Backhuys Publishers; 2006.

[23] Strugnell AM. A checklist of the Spermatophytes of Mt. Mulanje, Malawi. Scripta Bot Belgica 2006; 34: 1-199.

[24] Catarino L, et al. An annotated checklist of the vascular flora of Guinea-Bissau, West Africa. Blumea 2008; 53: 1-222. https://doi.org/10.3767/000651908X608179
[25] Figueiredo E, Smith GF. Plants of Angola. Pretoria: Strelitzia 22, South African National Biodiversity Institute; 2008.

[26] Figueiredo $\mathrm{E}$, et al. Annotated catalogue of the flowering plants of São Tomé and Príncipe. Bothalia 2011; 41(1): 4182.

https://doi.org/10.4102/abc.v41i1.34

[27] Brundu G, Camarda I. The Flora of Chad: A checklist and brief analysis. PhytoKeys 2013; 23: 1-18. https://doi.org/10.3897/phytokeys.23.4752

[28] Darbyshire I, et al. The plants of Sudan and South Sudan. London: Kew publishing, Royal Botanic Gardens, Kew; 2015.

[29] Adjossou K, et al. Forest land use and native trees diversity conservation in Togolese mega hotspot, Upper Guinean, West Africa. J Ecol Nat Environ 2019; 11(9): 127-42. https://doi.org/10.5897/JENE2019.0799

[30] Chhabra SC, Mahunnah RLA, Mshiu EN. Plants used in traditional medicine in eastern Tanzania. VI. Angiosperms (Sapotaceae to Zingiberaceae). J Ethnopharmacol 1993; 39: 83-103. https://doi.org/10.1016/0378-8741(93)90024-Y

[31] Hutchinson J, Dalziel JM. Flora of west tropical Africa vol 1 part 2. London: Crown Agents; 1958.

[32] Vasileva B. Plantes Medicinales de Guinee. Moscow: University of Moscow; 1969.

[33] Boyom FF, et al. Aromatic plants of tropical central Africa. Part XLII. Volatile components from Antidesma laciniatum Muell. Arg. var. laciniatum growing in Cameroon. Flavour Fragr J 2003; 18: 451-3. https://doi.org/10.1002/ffj. 1251

[34] Lautenschläger $\mathrm{T}$, et al. First large-scale ethnobotanical survey in the province of Uíge, northern Angola. J Ethnobiol Ethnomed 2018; 14: 51. https://doi.org/10.1186/s13002-018-0238-3

[35] Ndah NR, et al. Ethnobotanical study of commonly used medicinal plants of the Takamanda rainforest south west, Cameroon. Afr J Plant Sci 2013; 7(1): 21-34. https://doi.org/10.5897/AJPS12.111

[36] Neuwinger HD. Plants used for poison fishing in tropical Africa. Toxicon 2004; 44: 417-30. https://doi.org/10.1016/j.toxicon.2004.05.014

[37] Mbayo KM, et al. Contribution to ethnobotanical knowledge of some Euphorbiaceae used in traditional medicine in Lubumbashi and its surroundings (DRC). J Adv Bot Zool 2016; 4(2): 1-16.

[38] Cooper GP, Samuel JR. The Evergreen Forests of Liberia: A report on investigations made in the west African Republic of Liberia by the Yale University School of Forestry in Cooperation with the Firestone Plantations Company. Connectcut: Yale School of Forestry Bulletin 31; 1931.

[39] Gelfand $M$, et al. The traditional medical practitioner in Zimbabwe: His principles of practice and pharmacopoeia Gweru: Mambo Press; 1985.

[40] Latham P. Edible caterpillars and their food plants in BasCongo province, Democratic Republic of Congo. London: Department for International Development; 2015.

[41] Choi CW, et al. Antiproliferation effects of selected Tanzania plants. Afr J Trad Compl Alt Med 2015; 12(2): 96-102. https://doi.org/10.4314/ajtcam.v12i2.15

[42] K'Okul RNO. Maternal and child health in Kenya: A study of poverty, disease and malnutrition in Samia. Uppsala: Scandinavian Institute of African Studies; 1991.

[43] Kokwaro JO. Medicinal plants of East Africa. Nairobi: University of Nairobi Press; 2009.

[44] Dalziel JM. The useful plants of west tropical Africa. London: The Crown Agents for the Colonies; 1948.

[45] Quattrocchi U. CRC world dictionary of medicinal and poisonous plants: common names, scientific names, eponyms, synonyms, and etymology. London: CRC Press; 2012. 
[46] Iwu MM. Handbook of African medicinal plants. Boca Raton: CRC Press; 2014.

https://doi.org/10.1201/b16292

[47] Boyom FF, et al. Composition and anti-plasmodial activities of essential oils from some Cameroonian medicinal plants. Phytochem 2003; 64: 1269-75. https://doi.org/10.1016/j.phytochem.2003.08.004

[48] Tchinda AT, et al. Squalene and amentoflavone from Antidesma laciniatum. Bull Chem Soc Ethiopia 2006; 20(2): 325-8.

https://doi.org/10.4314/bcse.v20i2.61417

[49] Djouossi MG, et al. Chevalierinoside B and C: Two new isoflavonoid glycosides from the stem bark of Antidesma laciniatum Muell. Arg (syn. Antidesma chevalieri Beille). Phytochem Lett 2014; 9: 149-52. https://doi.org/10.1016/j.phytol.2014.05.013

[50] Djouossi MG, et al. Chevalierinoside A: a new isoflavonoid glycoside from the stem bark of Antidesma chevalieri Beille (Euphorbiaceae). Bull Chem Soc Ethiopia 2014; 28: 309-14. https://doi.org/10.4314/bcse.v28i2.16

[51] Buske A, et al. Benzopyranones and ferulic acid derivatives from Antidesma membranaceum. Phytochem 1997; 46(8): 1385-8. https://doi.org/10.1016/S0031-9422(97)00488-3

[52] Buske $A$, et al. Antidesmone, a novel type isoquinoline alkaloid from Antidesma membranaceum (Euphorbiaceae). Tetrahedron 1999; 55(4): 1079-86. https://doi.org/10.1016/S0040-4020(98)01107-7
[53] Bringmann G, et al. Biosynthesis of antidesmone in cell cultures of Antidesma membranaceum (Euphorbiaceae): an unprecedented class of glycine-derived alkaloids. J American Chem Soc 2000; 122(41): 9905-10.

https://doi.org/10.1021/ja001391k

[54] Bringmann G, et al. Antidesmone, a novel antitrypanosomal alkaloid. Pharmaceut Pharmacol Lett 2001; 11(2): 47-8.

[55] Buske A, et al. Alkaloidal, megastigmane and lignan glucosides from Antidesma membranaceum (Euphorbiaceae). European J Org Chem 2001; 18: 3537-43. https://doi.org/10.1002/10990690(200109)2001:18<3537::AID-EJOC3537>3.0.CO;2-A

[56] Magadula JJ, et al. Anti-Mycobacterial and toxicity activities of some priority medicinal plants from Lake Victoria basin Tanzania. European J Med Plants 2012; 2(2): 125-31. https://doi.org/10.9734/EJMP/2012/739

[57] Ogunlana EO, Ramstad E. Investigations into the antibacterial activities of local plants. PI Med 1975; 27: 354. https://doi.org/10.1055/s-0028-1097814

[58] Adewunmi CO, Sofowora EA. Preliminary screening of some plant extracts for molluscicidal activity. PI Med 1980; 39: 5765.

https://doi.org/10.1055/s-2008-1074903

Received on 19-07-2020

Accepted on 09-09-2020

Published on 15-10-2020

DOI: https://doi.org/10.29169/1927-5951.2020.10.05.11

(c) 2020 Alfred Maroyi; Licensee SET Publisher.

This is an open access article licensed under the terms of the Creative Commons Attribution Non-Commercial License (http://creativecommons.org/licenses/by-nc/3.0/) which permits unrestricted, non-commercial use, distribution and reproduction in any medium, provided the work is properly cited. 